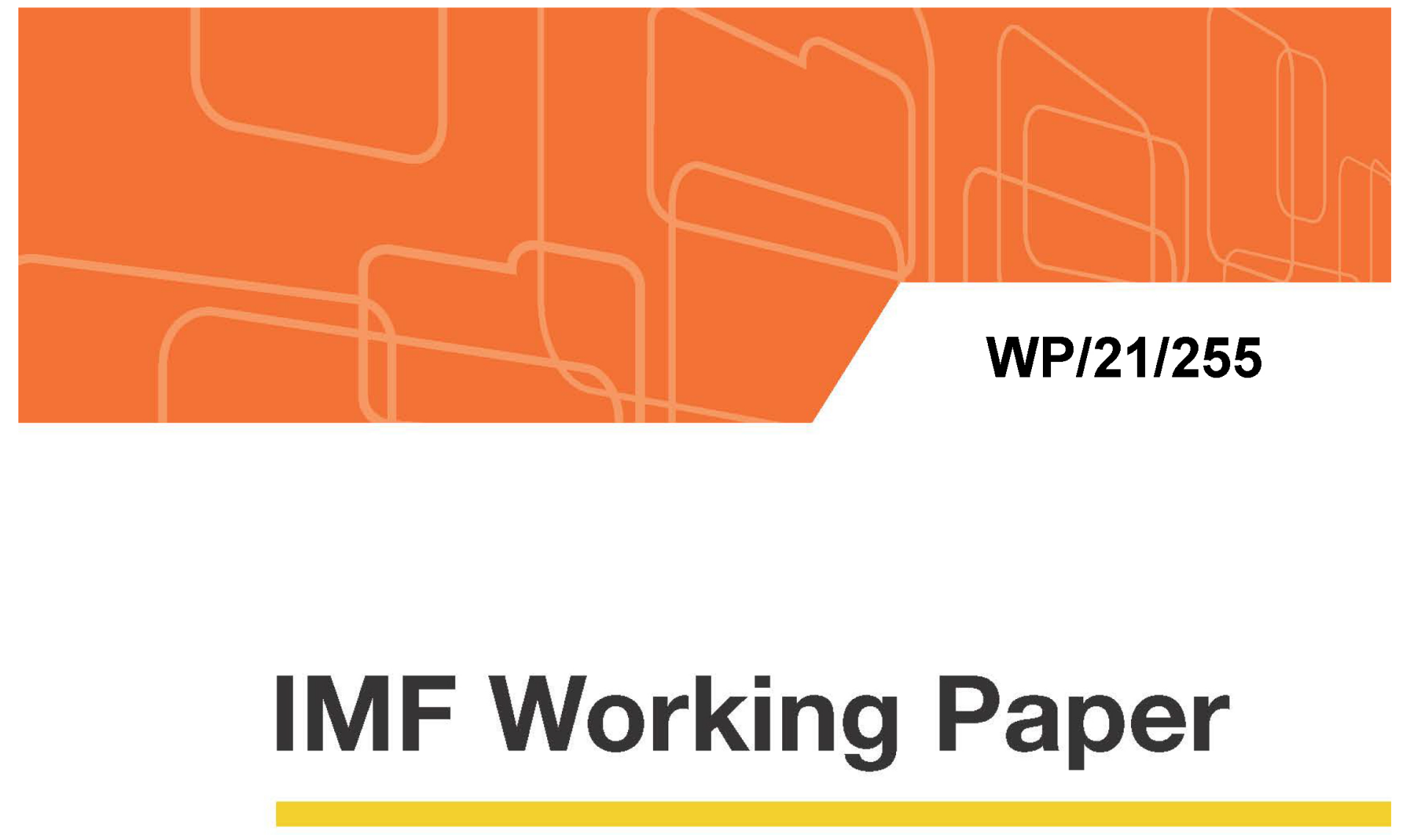

\title{
A Balance-Sheet Analysis of the Dutch Economy
}

by Ruo Chen

IMF Working Papers describe research in progress by the author(s) and are published to elicit comments and to encourage debate. The views expressed in IMF Working Papers are those of the author(s) and do not necessarily represent the views of the IMF, its Executive Board, or IMF management. 


\title{
IMF Working Paper
}

\author{
European Department
}

\section{A Balance Sheet Analysis of the Dutch Economy \\ Prepared by Ruo Chen ${ }^{1}$}

Authorized for distribution by Alfredo Cuevas

October 2021

\section{IMF Working Papers describe research in progress by the author(s) and are published to elicit comments and to encourage debate. The views expressed in IMF Working Papers are those of the author(s) and do not necessarily represent the views of the IMF, its Executive Board, or IMF management.}

\begin{abstract}
The Dutch economy is characterized by substantial financial balance sheets in the private sector. Uncommonly large gross financial assets and liabilities are found in the financial sector, whereas households own significant net financial wealth. The large gross financial assets and liabilities reflect a dominant role of multinational corporations (MNCs). Despite their size, these financial positions have not brought significant financial stability risks to the country. On the other hand, Dutch households' long balance sheets have been associated with depressed consumption and volatile real estate investment, which has probably exacerbated the cyclicality of the economy. The expected reform of the pension system is likely to change the way household balance sheets interact with private consumption.
\end{abstract}

JEL Classification Numbers: G11, G20, G30, G50

Keywords: balance sheet, financial accounts, multinational corporation, household, pension Author's E-Mail Address: $\underline{\text { rchen@imf.org }}$

\footnotetext{
${ }^{1}$ The author would like to thank Alfredo Cuevas, Woon Gyu Choi, and Tumer Kapan for their valuable comments, as well as comments from the Dutch Central Bank, Ministry of Finance, and Ministry of Social Affairs. All views and errors are those of the author.
} 


\section{TABLE OF CONTENTS}

Abstract

I. Introduction $\underline{4}$

II. Financial Balance Sheets of the Dutch Economy $\underline{5}$

III. Financial Balance Sheets of Financial and Non-Financial Corporations 1

IV. Financial Balance Sheets of Households $\underline{11}$

V. Conclusion $\underline{14}$

References $\underline{21}$

Figures

1. Selected European Countries: Gross Financial Assets and Liabilities by Sector

2. Gross Financial Assets and Liabilities by Sector

3. Net Financial Assets and Liabilities by Sector

4. Gross Financial Assets and Liabilities - Financial Corporations

5. FDI Held by SFIs and Non-SFIs

6. Gross Financial Assets and Liabilities - Non-Financial Corporations

7. Non-Financial Corporation Leverage

8. Changes in Financial Assets and Liabilities in 2020

10. Household Consumption and Real GDP 4

\section{Annexes}

I. External Imbalances of the Dutch Economy 16

II. Cross-Sector Financial Linkages 17

III. An Overlapping Generations Model $\underline{18}$

IV. Evolution of Dutch Pension Funds

$\underline{20}$




\section{INTRODUCTION}

The Netherlands is characterized by the extraordinarily large gross financial assets and liabilities found in the balance sheets of its firms, households, and financial intermediaries (Figure 1). The country's aggregate foreign assets and liabilities are also uncommonly large relative to the size of the economy (Annex I). Using financial transactions and balance sheet data for major institutional sectors, this paper documents the evolution of the imbalances in the Dutch economy, explores potential vulnerabilities, and considers macroeconomic implications by analyzing sectoral stocks and flows of financial assets and liabilities. With the latest quarterly data covering 2020Q4, this paper also discusses the development of corporate and household financial positions during the COVID-19 pandemic. This type of balance sheet analysis has been increasly deployed in the Fund's bilateral and multilateral surveillance (IMF 2015). However, it must be noted upfront that balance sheet analysis has some limitations. The sectoral financial balance sheet data does not include non-financial assets and off-balance sheet exposures, which may affect a sector's vulnerability to crisis. Also, aggregate balance sheet information for a sector may mask within-sector differences, especially the presence of pockets of vulnerability.

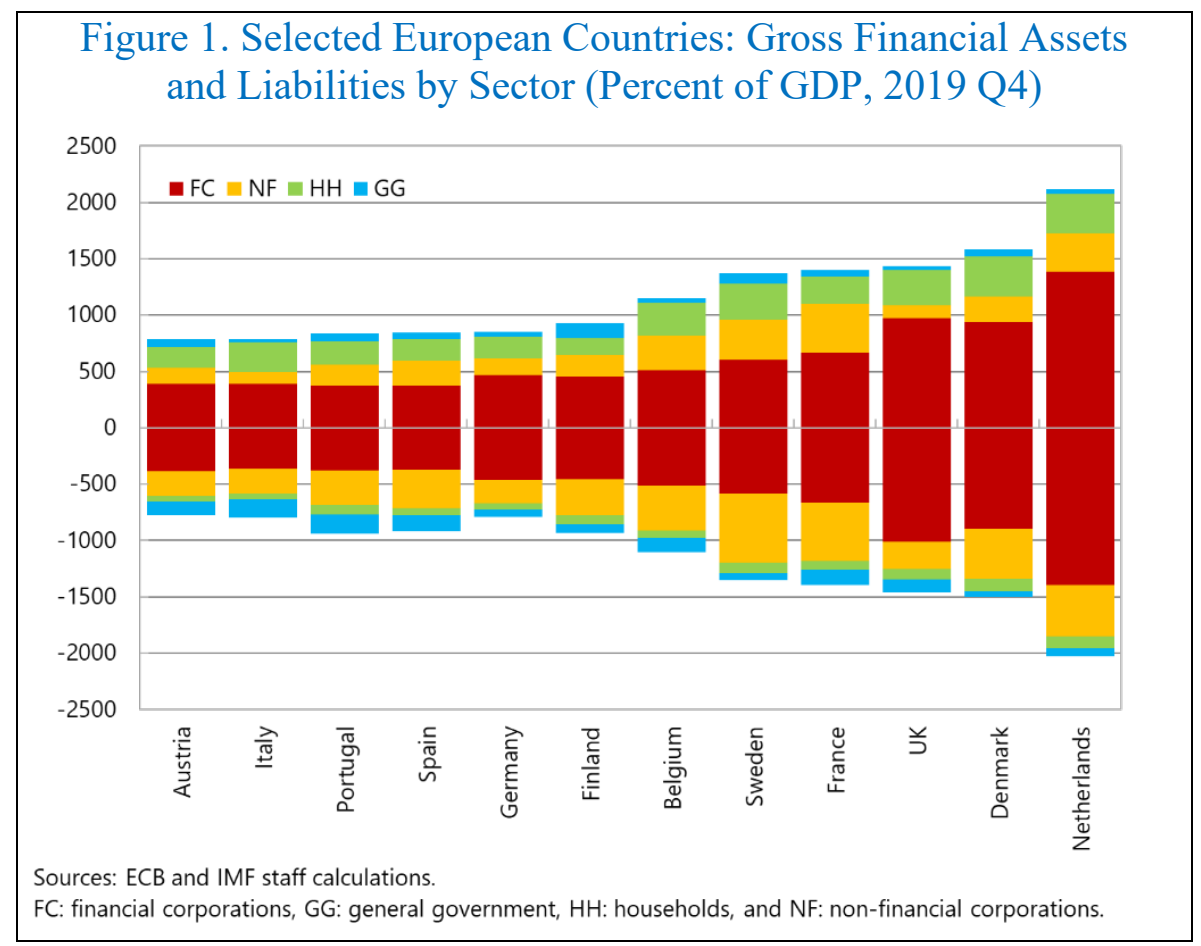

The data show that the enormous gross financial assets and liabilities are related to a significant extent to the activities of multinational corporations (MNCs). Despite their size, these positions have not brought significant financial stability risks to the country, although MNCs could still transmit external shocks to the Netherlands through trade and investment linkages. The financial positions of the non-financial corporate (NFC) sector and financial sector remained stable in 2020, a testament to the resilience of the country and the policy response to the COVID shock. The aggregated information pointed out that corporates 
moved towards market financing during the pandemic, which could be dominated by MNCs and large firms' financing activities.

On the contrary, Dutch households' large balance sheets may have important macroeconomic effects in the country. The low-interest-rate environment and limited options in the housing market have depressed private consumption and led to more volatile real estate investment, which could further exacerbate the cyclicality of the economy. Household financial wealth continued to rise during the pandemic, reflecting in large part higher valued pension entitlements, but also extraordinary saving, as household consumption opportunities declined (while disposable income was supported by emergency policy support measures). The consumption behavior over the medium term will likely depend on the upcoming pension reform, which could change the way balance sheet changes affect consumer behavior.

The remainder of this paper is structured as follows. The following section discusses the dynamics of gross and net financial assets and liabilities of the whole Dutch economy, highlighting very different sectors dominating the gross and net financial positions. The financial sector has the largest gross financial assets and liabilities, whereas Dutch households mostly own the net financial wealth. Therefore, sections III and IV look into the detailed financial positions of the financial sector and households, respectively. Section III also covers the NFC sector and its links with MNC activities. Both sections pay special attention to the potential factors driving corporate and household financial positions' evolution and their associated macro-economic and financial vulnerabilities. Section $\mathrm{V}$ concludes.

\section{Financial Balance Sheets of the Dutch Economy}

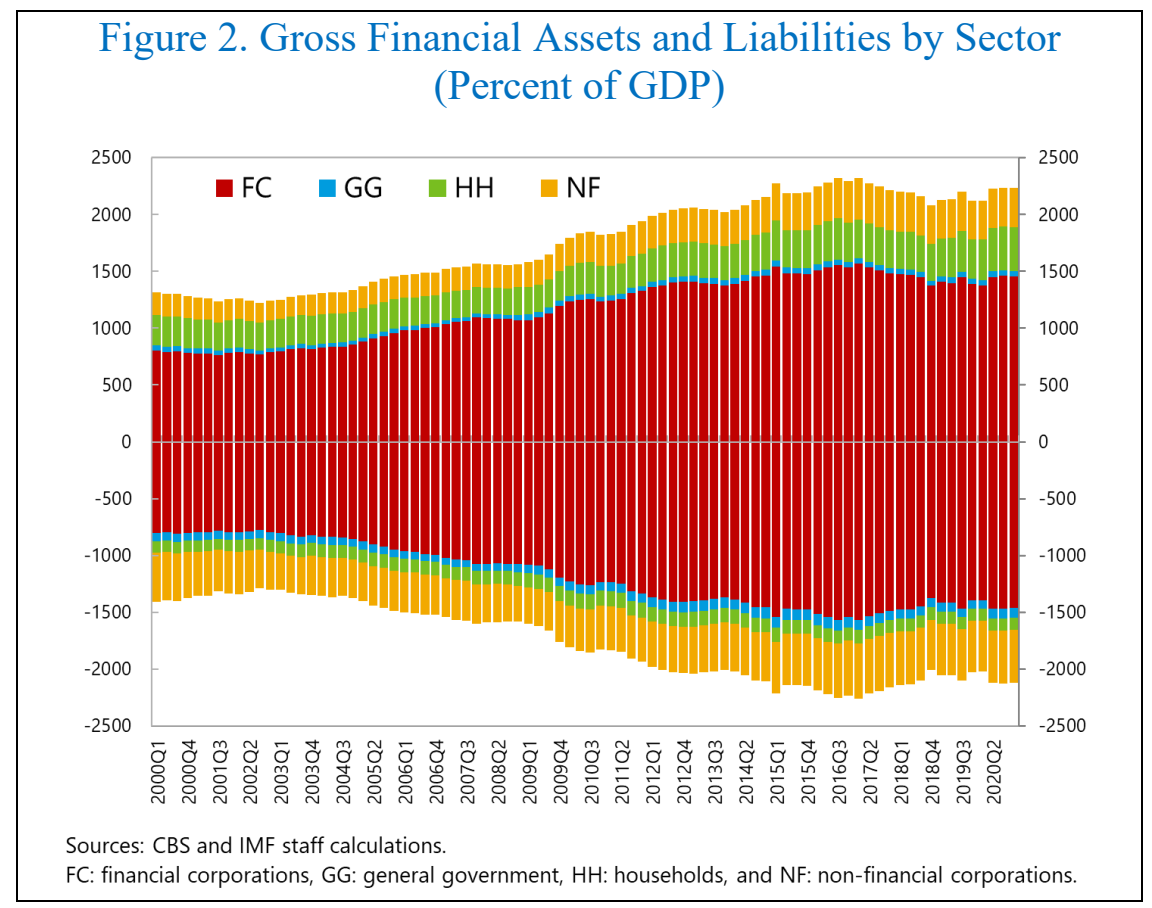


The Netherlands' gross financial assets and liabilities are enormous, at more than 20 times GDP, having shown very fast growth in the first two decades of this century. The expansion of both assets and liabilities started around the early 2000s, peaked in 2017, and declined moderately in relation to GDP in recent years (Figure 2). In 2020, both financial assets and liabilities remained stable as a share of GDP. Among the institutional sectors, the financial sector holds the most significant shares of financial assets and liabilities of the country. It is also the main contributor to the expansion of financial balance sheets since the early 2000s. This reflects the Netherlands' growing role as a financial center, including the presence of MNCs.

The net financial assets of the Netherlands as a country also increased significantly over the past 20 years, taking it from a net debtor position of about 100 percent of GDP to a net creditor position of around 110 percent of GDP (Figure 3). The improvement of the country's net financial assets was led by the decline of NFCs' net financial liabilities before the GFC, followed by a notable increase in household's net financial assets after the GFC. Based on the net financial asset positions, Dutch households are the sector with the largest net financial creditor position, whereas the NFC sector and the government have net financial debtor positions. The financial sector's gross assets and liabilities are roughly balanced over time, as can be expected given its financial intermediation function.

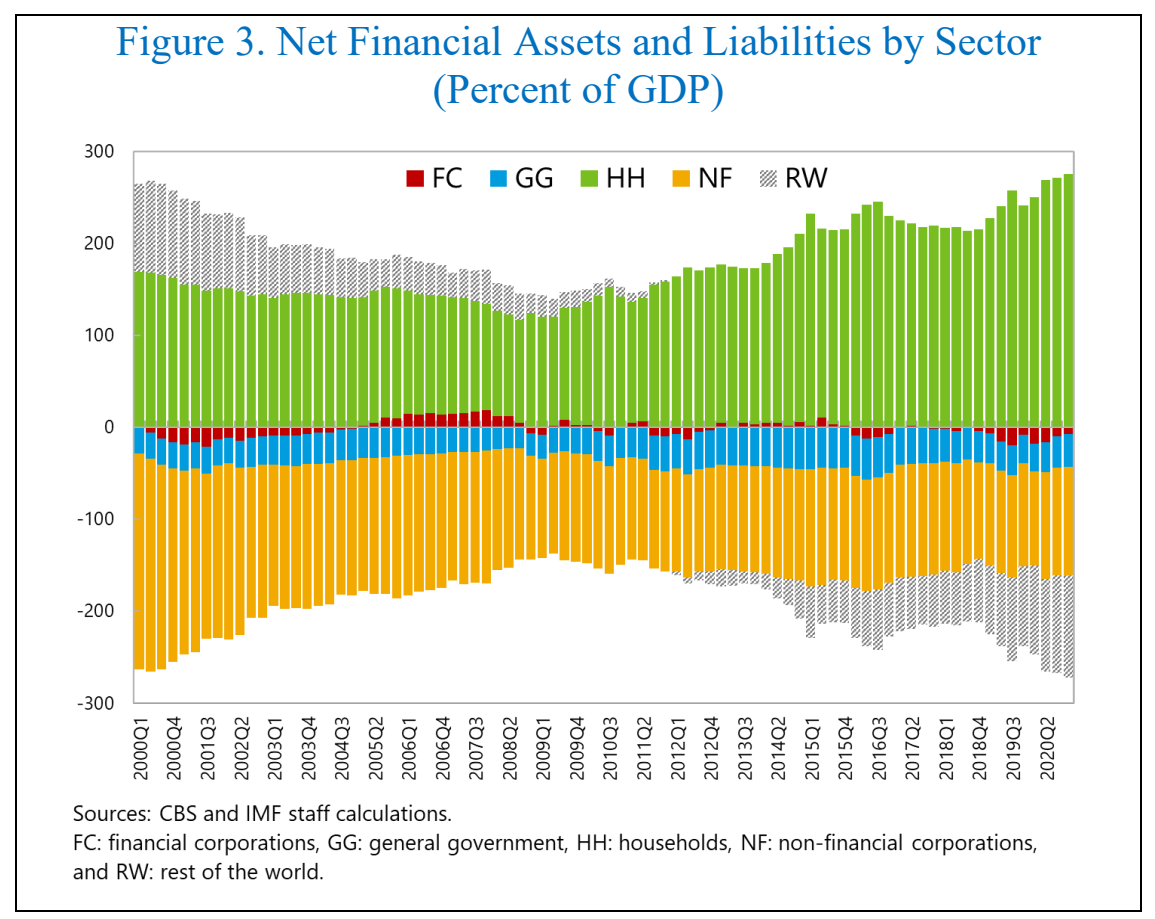

In 2020, while the NFC sector and government's net financial liabilities increased slightly, households' net financial assets continued to rise by a remarkable 35 percent of GDP. The increase of households' net financial wealth during the pandemic, to a large extent, is due to a continued rise in households' financial assets in nominal terms. This had as its main reflection a continued increase of the Netherlands' net financial claims on the rest of the world, which reached 111 percent of GDP at the end-2020. 


\section{Financial Balance Sheets of Financial ANd Non-Financial Corporations}

In the financial sector, the expansion of gross financial stocks primarily reflects a substantial increase in equity positions. ${ }^{2}$ As a ratio to GDP, the size of the balance sheets (represented by the sum of assets plus liabilities) of the financial sector increased by more than thirteen hundred percentage points over the past 20 years (Figure 4). More than half of the increase (seven hundred percentage points) can be explained by rising equity positions. Despite some valuation losses in 2020Q1, the financial corporations' equity positions recovered quickly and continued to grow throughout the remainder of 2020.

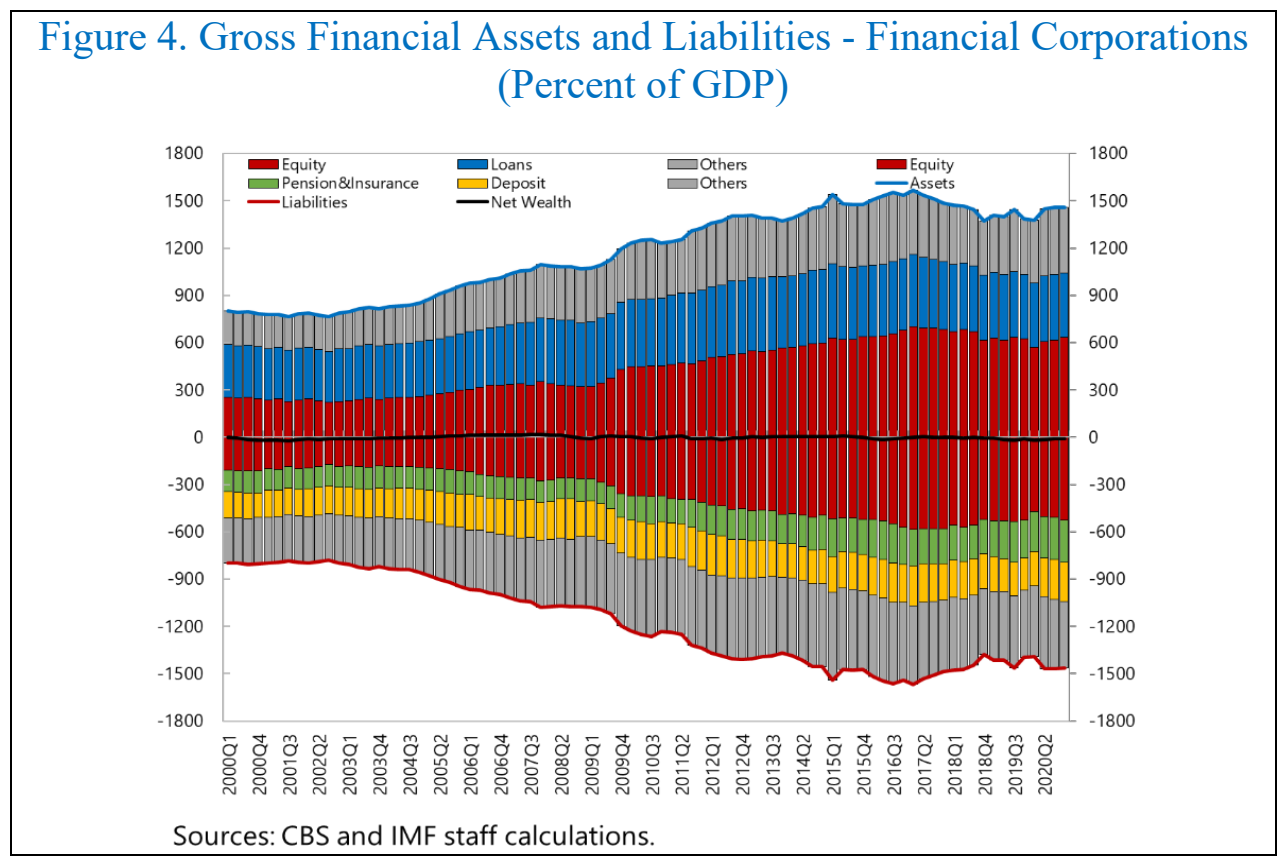

The rise in equity positions, in turn, reflects the increasing weight of FDI in the Netherlands' international investment position (IIP). The 2019 Coordinated Direct Investment Survey (CDIS) shows that the Netherlands is the world's largest recipient and the second largest provider of global direct investment. The surge of FDI claims and liabilities reflects the growing activities of the special financial institutions (SFIs), similar to the special purpose vehicles (SPVs). ${ }^{3}$ SFIs in the Netherlands hold more than 60 percent of the cross-border FDI till 2019; they grew very fast through the end of the euro area crisis, and more or less stabilized from 2014; but they then dropped markedly in 2020 (Figure 5). ${ }^{4}$ SFIs act as financial intermediaries between various parts of MNCs to which they belong (Hers et al. 2018). The financial assets and liabilities of SFIs usually are related to investment originating

\footnotetext{
2 The financial sector includes the central bank, deposit-taking corporations and money market funds (MMFs), insurance corporations and pension funds, and other financial institutions (including non-MMF investment funds and other financial institutions excluding investment funds).

${ }^{3}$ SFIs are resident Dutch enterprises or institutions but are wholly owned by foreign investors.

${ }^{4}$ In 2020, FDI flows and stocks (both inwards and outwards) declined marginally. The significant decline of FDI held by SFIs is likely due to the reclassification of some SFIs.
} 
in a foreign country and going to a third country, channeled via the Netherlands (Annex II), and less involved in domestic economic activities. SFIs also manage dividends, interest, and royalty flows within MNCs. Non-SFI foreign direct investment activities grew in importance since 2014.

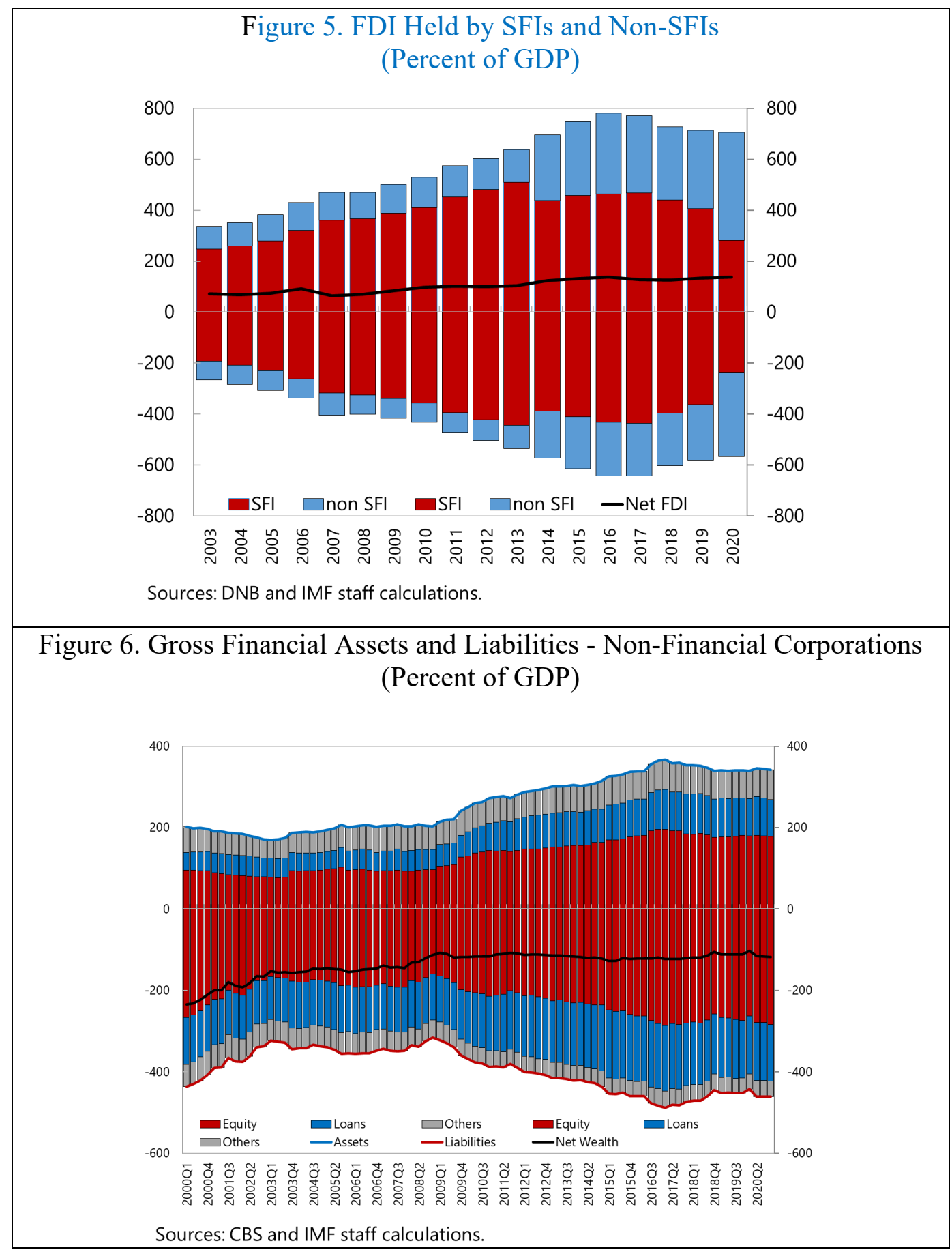

The evolution of NFC's balance sheets also reflects MNCs' activities. The equity liabilities in the NFC sector fell by almost 100 percent of GDP from the early 2000s to 2008, leading to an increase in NFCs' net financial assets of more than 100 percent of GDP (Figure 6). This is 
mainly due to the shrinking of stock values after the tech bubble burst. Since the GFC, while the net financial asset positions have remained stable, assets and liabilities have increased by more than 130 percent of GDP.

Like the financial sector, a significant part of the increases in the NFC's financial assets and liabilities was driven by rising equity positions, leading to a considerable decline of the average leverage ratio (defined as the ratio of debt liabilities to equity liabilities) of the NFC sector (Figure 7). Remarkably, the leverage ratio of NFCs did not rise during the pandemic, unlike in previous crises, when firm equity collapsed and debt rose. This reflects, to a large extent, the equity-preserving features of the emergency policy interventions implemented by the government, a phenomenon that could also be observed in other countries in Europe (Arena et al. 2021).

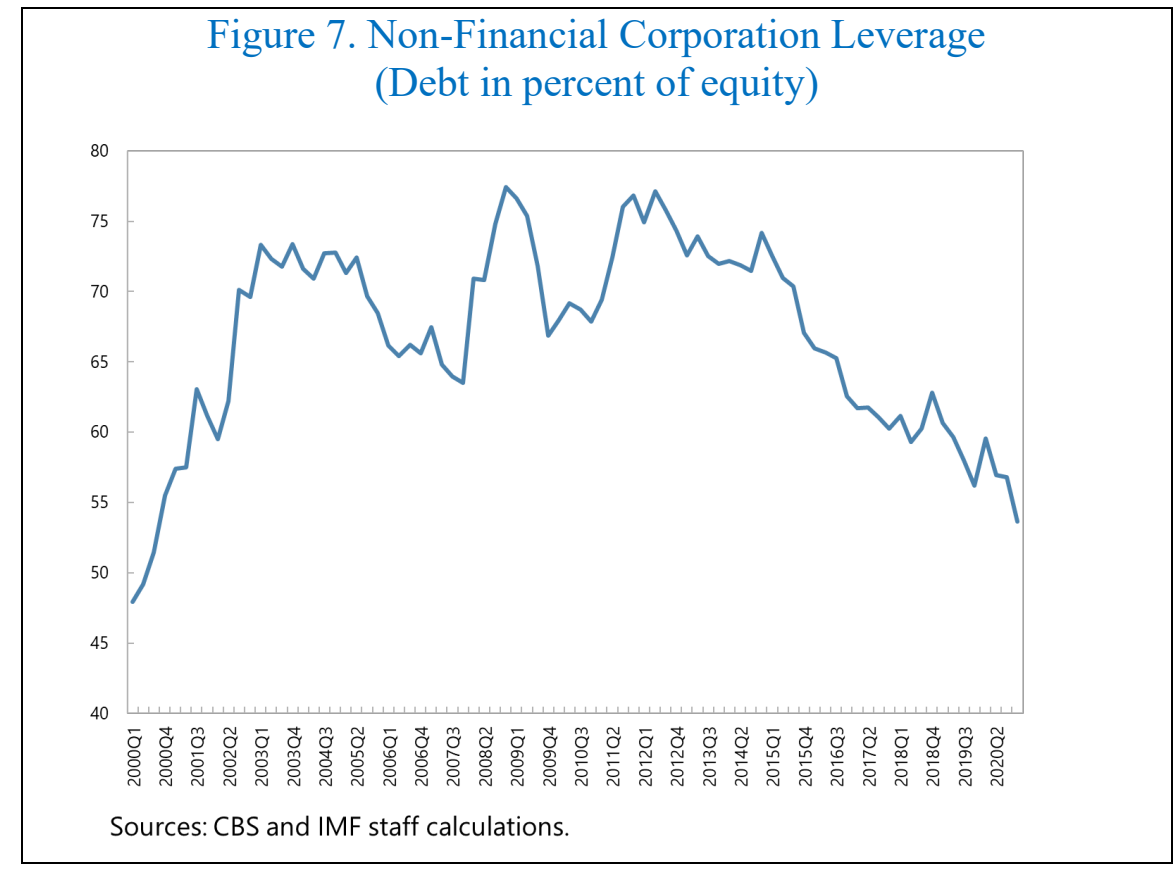

Lane and Milesi-Ferretti (2017) explain that both the growing importance of SPVs and the increasing tendency of MNCs to move their domicile to financial centers contributed to the rising cross-border FDI in financial centers since the GFC. As more MNCs located or moved their regional headquarters into the Netherlands, the NFC sector's balance sheets grew, reflecting increased cross-border equity and loans (particularly intercompany loans) ${ }^{5}$. While the Netherlands' NIIP and net FDI position are both positive, the net financial positions of the NFC sector and the financial sector were negative by about 120 percent of GDP and 10 percent of GDP at end-2020, respectively. ${ }^{6}$

\footnotetext{
${ }^{5}$ Intercompany loans are loans made between two business units of a company.

${ }^{6}$ Recall that net financial positions of corporations by definition exclude nonfinancial assets, including their productive assets.
} 
The enormous cross-border stock positions, particularly by MNCs, have had a limited impact on domestic vulnerability so far. The financial assets and liabilities of SPVs are generally matched and tend to move together. Therefore, parallel reductions or increases in SPVs' assets and liabilities do not affect the domestic economy. For example, after the U.S. tax reform and measures announced in the Netherlands to strengthen the corporate tax system, the inward and outward FDI stocks were reduced together by about 130 percent of GDP during 2017 and 2018. The reductions are about 70 percent of GDP on the asset side and 60 percent of GDP on the liability side, in which more than 80 percent of the declines were in SPVs. The impact on the domestic economy was not noticeable. However, the integration in the global value chain (GVC), related to MNCs' presence, makes the Netherlands vulnerable to external shocks. The global trade tensions since the end-2018 had a significant impact on Dutch exports, with potential spillover to the domestic economy through investment and jobs. That said, these are not balance sheet effects, but effects of the presence of MNCs in the Netherlands.

The net financial position of the financial sector has remained stable so far in the pandemic (i.e., in 2020), although its balance sheet shows some effects of the crisis. While there was little change to the financial sector's net financial position, financial firms' currency and deposits on both the asset and liability sides increased by more than 30 percent of GDP in 2020 (Figure 8). This reflects precautionary saving and forced curtailment of consumption opportunities (households) and the aim of raising liquidity buffers (corporates), in a context of policy support that ensured the availability of liquidity for corporates and households. The financial sector's lending (loans) declined marginally while holdings of debt securities increased, probably reflecting in part the purchase of government bonds issued to finance emergency support measures (Arena et al. 2021).

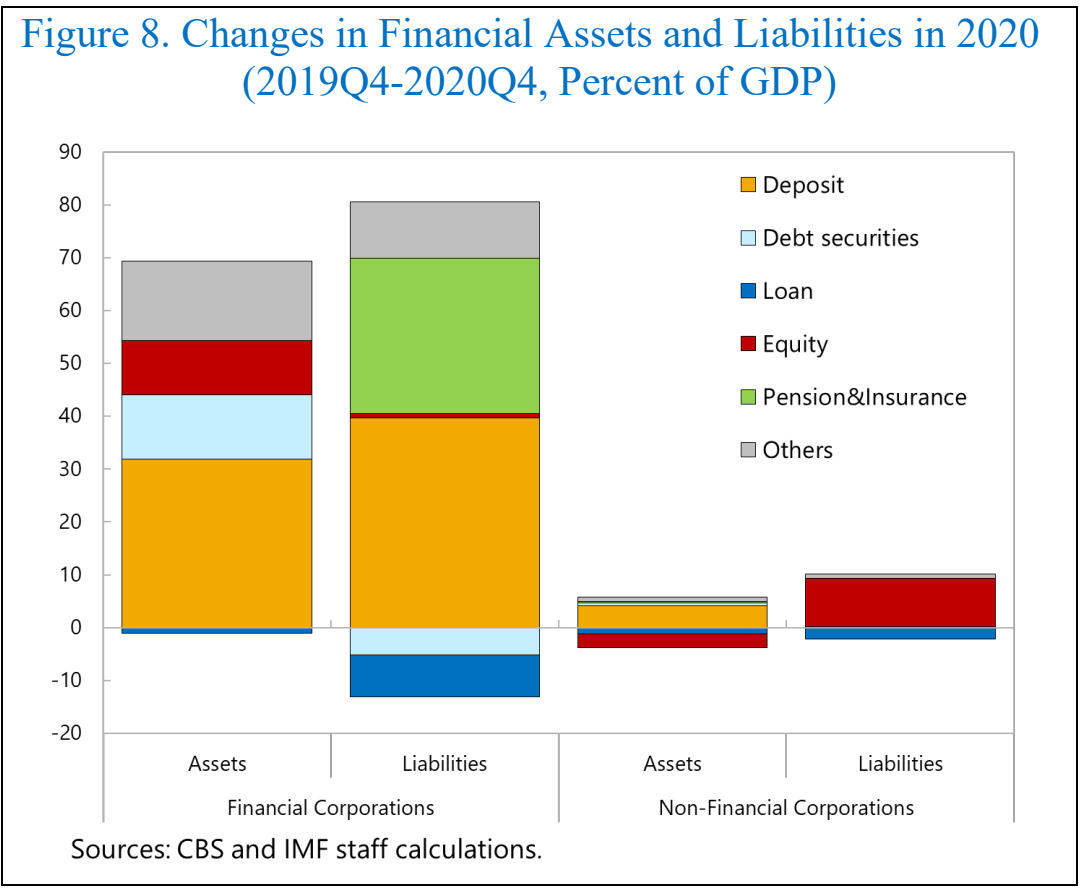


Similarly, NFCs' loan liabilities also decreased in the pandemic. Instead, NFCs raised capital and built liquidity buffers, enabled by strong government support programs. The picture is consistent with the idea that programs with a direct grant element have dominated, while bank borrowing under various guarantee programs has been used only to a small extent. Overall, the NFC sector's net financial worth declined by about 8 percent of GDP in 2020, although the different impact of the pandemic across firms and industries suggests there may have been sizable within-sector differences. The aggregated sectoral information pointed out that both the NFC sector and the financial sector moved towards market financing channels during the pandemic. However, without more details on within-sector differences, it is hard to say how much of the change in the aggregated sectoral data could be explained by MNCs and large firms.

\section{Financial Balance Sheets of Households}

Dutch households have enormous net financial wealth. Before 2008, household net financial assets had declined somewhat on the back of depreciating household assets (equity holdings) and rising household liabilities (mainly in mortgage loans, Figure 9). Since 2008, however, household net financial assets have been on an upward path driven by a remarkable rise in the value of pension entitlements, reflecting in part declining interest rates.

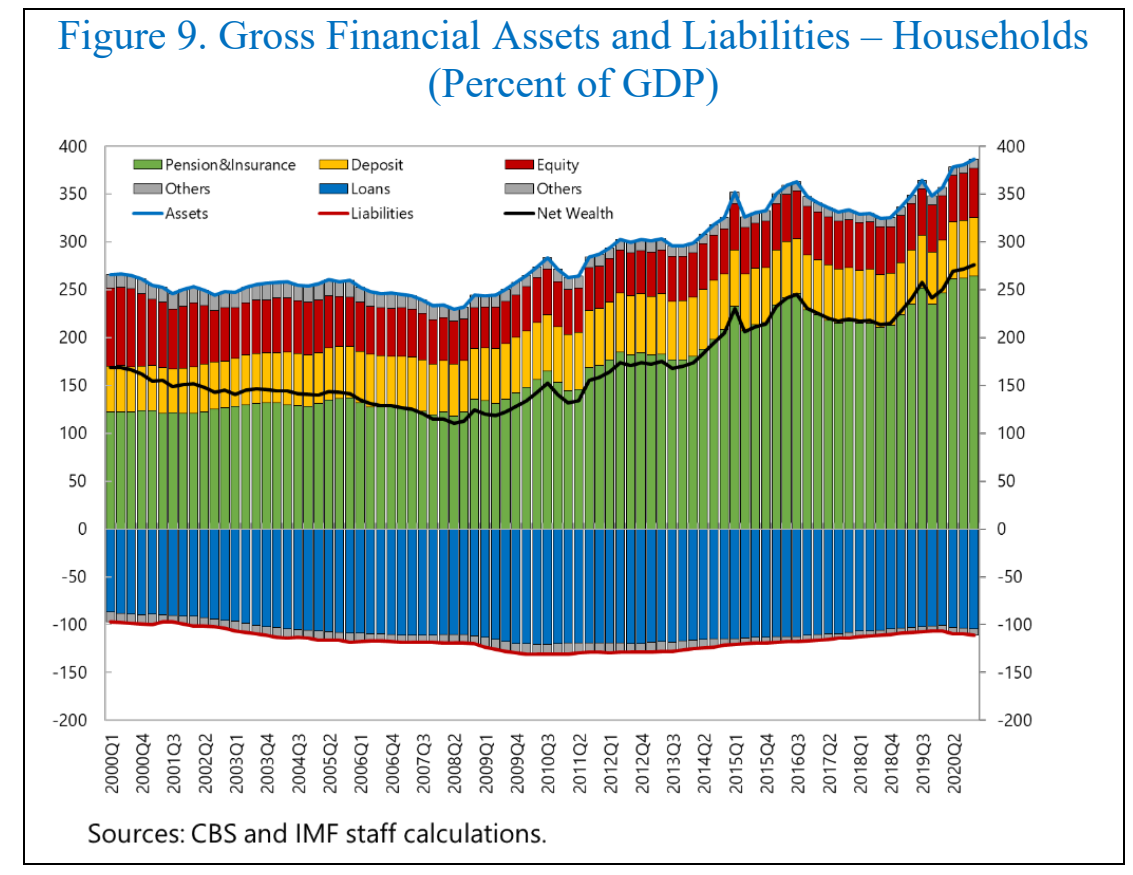

The Dutch pension system is dominated by the second pillar of fully funded, occupational, defined benefit (DB) schemes. Under the DB schemes, pension funds' liabilities (the counterpart of households' pension assets) are calculated as the present discounted value of promised future pension benefits, with risk-free interest rates to do the discounting. Therefore, declining interest rates led to the rapid increases in the value of pension funds' liabilities, above and beyond the part of their growth arising from the accrual of additional benefits for active contributors. At the end-2019, household pension assets were about 
210 percent of GDP: the highest in the world as a share of GDP. Household pension assets continued to increase in 2020 by about 30 percent of GDP. The Dutch pension system is ranked the world's best in 2020 (Mercer 2020), given, inter alia, that the system's liabilities are backed by commensurate assets. During the pandemic, the value of pension funds asset portfolios fluctuated markedly, reflecting the volatility of bond and stock markets; a drop in value experienced in 2020-Q2 was made up one year later as markets recovered and with them the solvency ratios of pension funds.

On the liability side, household debt has declined somewhat since the GFC, owing to the tightening of macroprudential policies, but reversed slightly in 2020. Household net financial wealth stood at 276 percent of GDP at the end of 2020, 35 percent of GDP higher than the end-2019 level.

Despite their rising financial wealth, households' consumption remained subdued even before the pandemic. Household real consumption increased only marginally - in fact, much less than GDP, over the past twenty years (Figure 10). At end-2019, household consumption was only five percent higher than the level at the beginning of 2000 and was the same as the pre-GFC peak. During this period, household consumption growth in the Netherlands was lower than in many European peers and only higher than in Italy, which experienced much more significant GDP losses since the GFC. In contrast, the Netherlands' real GDP per capita has grown faster than the euro area average. One possible reason that consumption did not increase much in the face of rising financial wealth as measured by the aggregate statistics could be that, from the point of view of the individual participant in a DB pension scheme, the measured increase in her wealth was not relevant, as the expected flow of her future benefits was not changing, even if its present discounted value was rising. In 2020, driven by the pandemic, household consumption declined by about seven percent despite the further increase of their net financial wealth.

Depressed household consumption over the last decade or so was also likely related to the low-interest-rate environment and its interaction with the particular features of the occupational DB pension schemes. Annex III illustrates this situation using a standard overlapping-generation (OLG) model with three cohorts, young, middle-aged, and old-aged. When interest rates decline, young households tend to increase their consumption as substitution effects dominate; in contrast, middle-aged households tend to reduce their consumption as income effects dominate. Since the middle-aged baby boomers have a larger share in the population, we expect that overall household consumption declines when the interest rate decreases. Moreover, when the interest rate falls, the return on pension assets also decreases, and pension contribution rates need to increase to maintain the guaranteed future pension income (Beetsma et al. 2015, Ciurila et al. 2020, and Parlevliet and Kooiman 2015). In this case, both young and middle-aged households would reduce their consumption, and we would see additional downward pressure on household consumption. If some households cannot borrow to offset the rise in contributions, household consumption could be further depressed. Indeed, through the period following the euro area crisis, many pension funds increased contribution rates to maintain their solvency ratios, which were under stress due to increased valuations of pension entitlements, or suspended the cost of living 
indexation of benefits for the same reason. Higher contribution rates and frozen real benefits must have contributed to holding consumption back.

High contribution rates, necessitated by the system's high replacement rates in a low-interest rate context, might also help explain the declining share of active pension contributors in total employment, as more and more self-employed opted out of the second pillar pension schemes (Annex IV, IMF 2019b). It is not easy to determine an optimal replacement rate, but the rise in self-employed represents individuals who have effectively opted out of the second pension pillar and its contributions. This drive would seem to coincide with employers' interest in keeping their own labor costs down. This fact could signal that the replacement rate (and its attendant contribution rates) could be on the high side in the Netherlands.

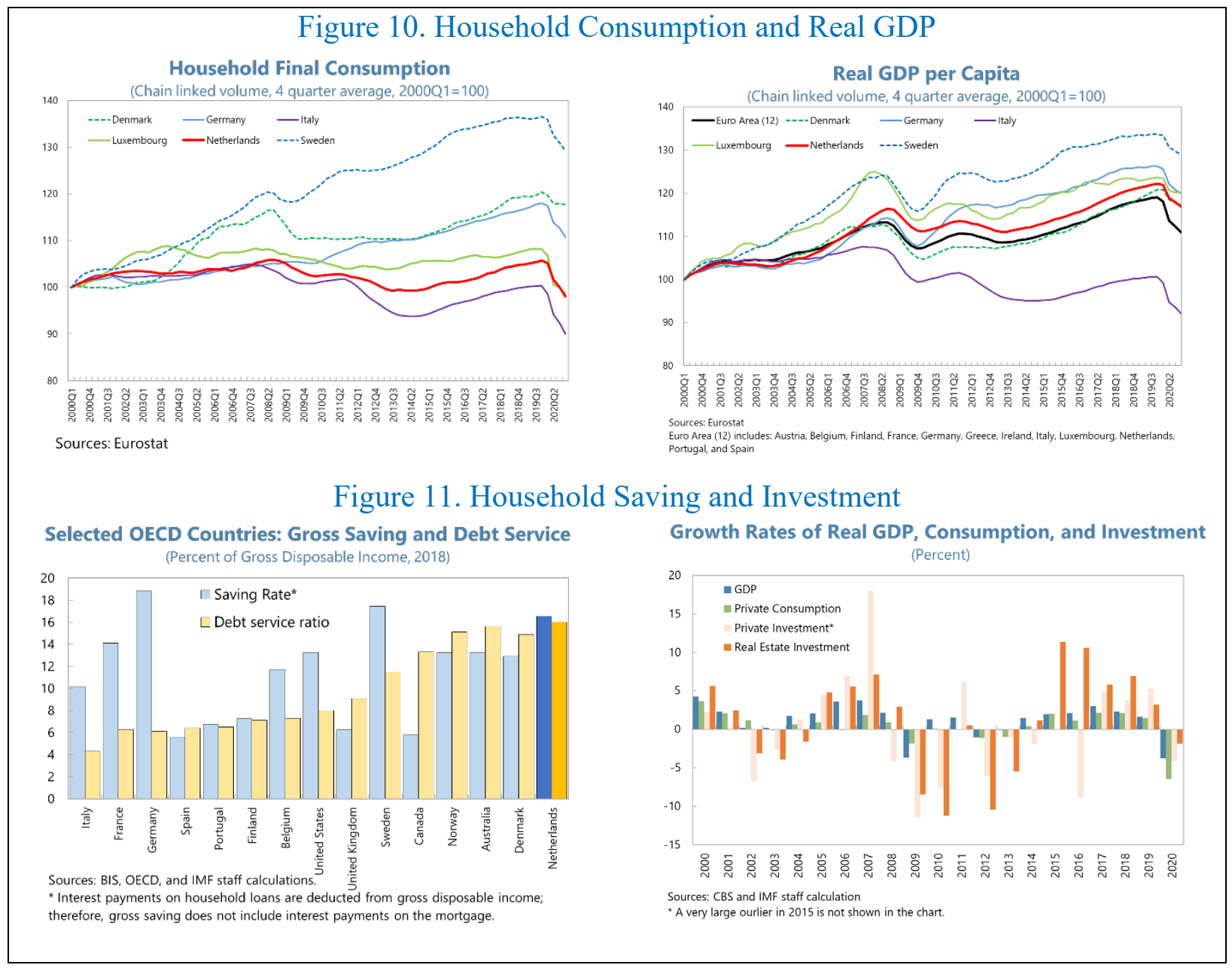

High mortgage payments also have constrained household consumption. Due to the shortage in the middle-range private rental market and debt-bias in the tax system (notably, the generous mortgage interest deductibility), homeownership supported by debt is very high in the Netherlands (IMF 2018, Heeringa et al. 2019, Geis and Luca 2021, and Klemm et al. 2021). As a result of the insufficient supply of rental units, demand for owner-occupied housing has been strong, housing prices have increased rapidly, and households ended up with high mortgage debt and mortgage payments. Compared with other OECD countries, the 
high level of Dutch household savings could reflect, to a significant extent, the need to make large debt service payments (Figure 10). Therefore, the high level of mortgage debt may be dampening household consumption as well. For the self-employed, debt pressure plays a more dominant role than the compulsory pension contribution (Caloia et al. 2021).

As a result of these institutional features, in a low-interest-rate environment, the long balance sheets of Dutch households can, instead of spurring it, hold back the growth of consumption, which is a significant expenditure component of GDP. The rising household net financial wealth has not led to higher household consumption even before the pandemic. On the contrary, real household consumption has not increased much since the GFC, despite a robust recovery of real GDP growth. Households did contribute to domestic demand, rather more through residential investment than through private consumption, but this may also have contributed to the volatility of the economy, as investment tends to be more volatile than consumption. In fact, real estate investment in the Netherlands shows very strong comovement with GDP with much higher volatility than GDP and consumption (Figure 10).

\section{CONCLUSiON}

The Dutch economy is characterized by substantial financial balance sheets in the private sector. Using the detailed financial transactions and balance sheets data of institutional sectors, this paper shows enormous gross financial assets and liabilities in the financial sector, whereas households own substantial net financial wealth.

The breakdown of the financial sector's financial assets and liabilities indicates a dominant role of MNCs' activities. The rise in equity positions since the GFC reflects the growing activities of SFIs, which act as financial intermediaries between various parts of MNCs to which they belong. MNCs' activities also affect the NFC's financial balance sheets, reflecting rising equity financing and declining leverage (debt liabilities in percent of equity liabilities). Despite their size, these financial positions have not brought significant financial stability risks to the country, although MNCs could still transmit external shocks to the Netherlands through trade and investment linkages. The financial positions of the NFC sector and the financial sector remained stable in 2020, with MNCs' access to market financing and government support.

On the other hand, Dutch households' long net creditor position can give rise to unexpected macroeconomic effects, owing to the size and structure of their considerable financial assets and liabilities. Their long balance sheets seem to have been associated in the last decade or so with depressed consumption and volatile real estate investment, which could further exacerbate the cyclicality of the economy. Household financial wealth continued to rise during the pandemic, primarily due to higher valued pension entitlements; but such valuation gains should not be expected to support sustained post-pandemic consumption recovery through textbook wealth effects. The agreed pension reform implies a move from a definedbenefit model towards modalities with capitalization features tempered by some risk sharing; thus, it is likely to change the way aggregate private consumption is affected by wealth and interest rates going forward, although it is too early to tell what this change will ultimately look like (the pension reform will not go into effect for some years yet, and many important details are still being worked out). Additional measures to continue to reduce debt biases in 
the tax system (Geis and Luca 2021 and Klemm et al. 2021) and foster the supply of rental homes would also help moderate vulnerabilities associated with household consumption and debt gradually over time, enhancing macroeconomic stability. 
ANNEX I. EXTERNAL IMBALANCES OF THE DUTCH ECONOMY

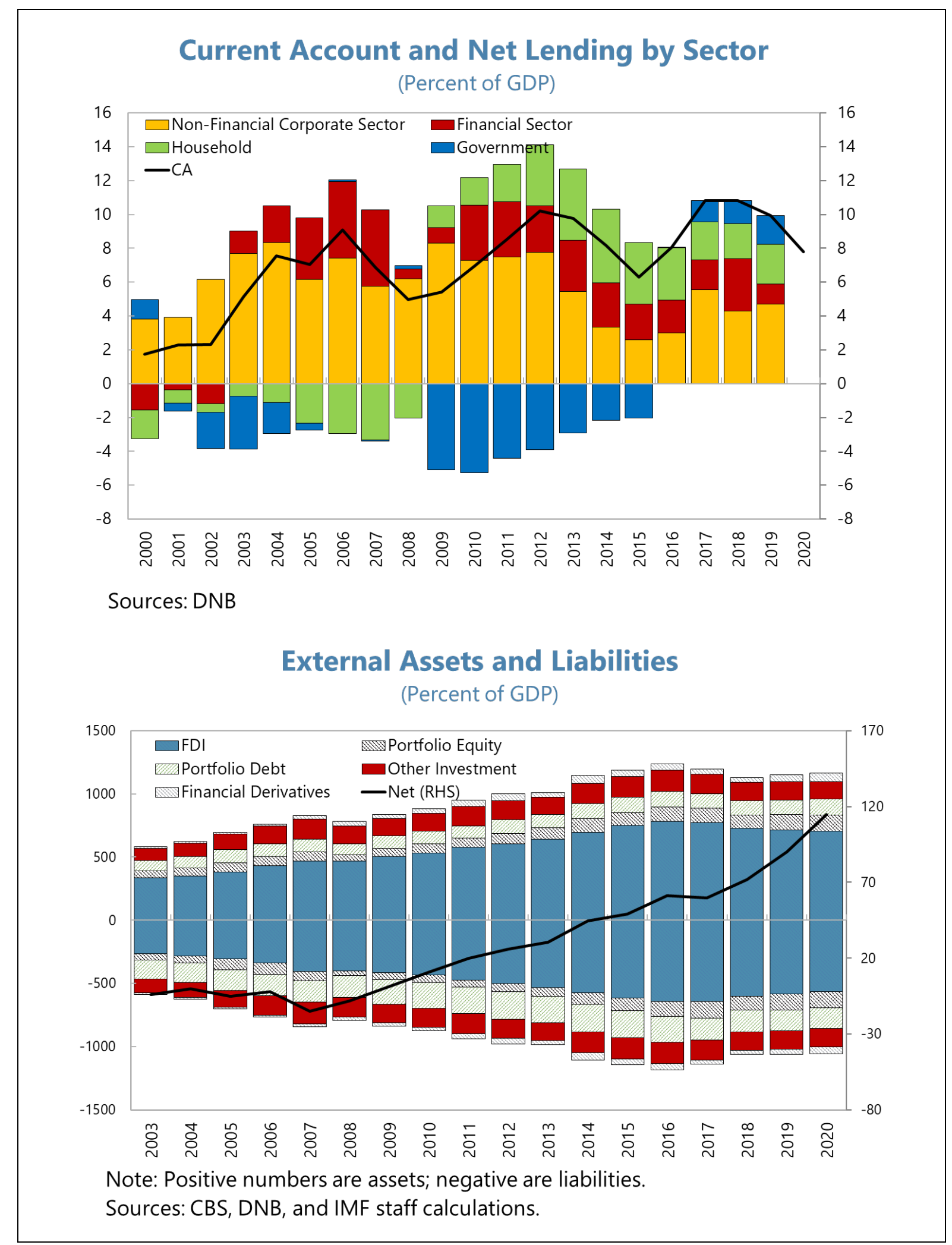

CInternational Monetary Fund. Not for Redistribution 
AnNeX II. Cross-Sector FinANCIAL LinkAgeS

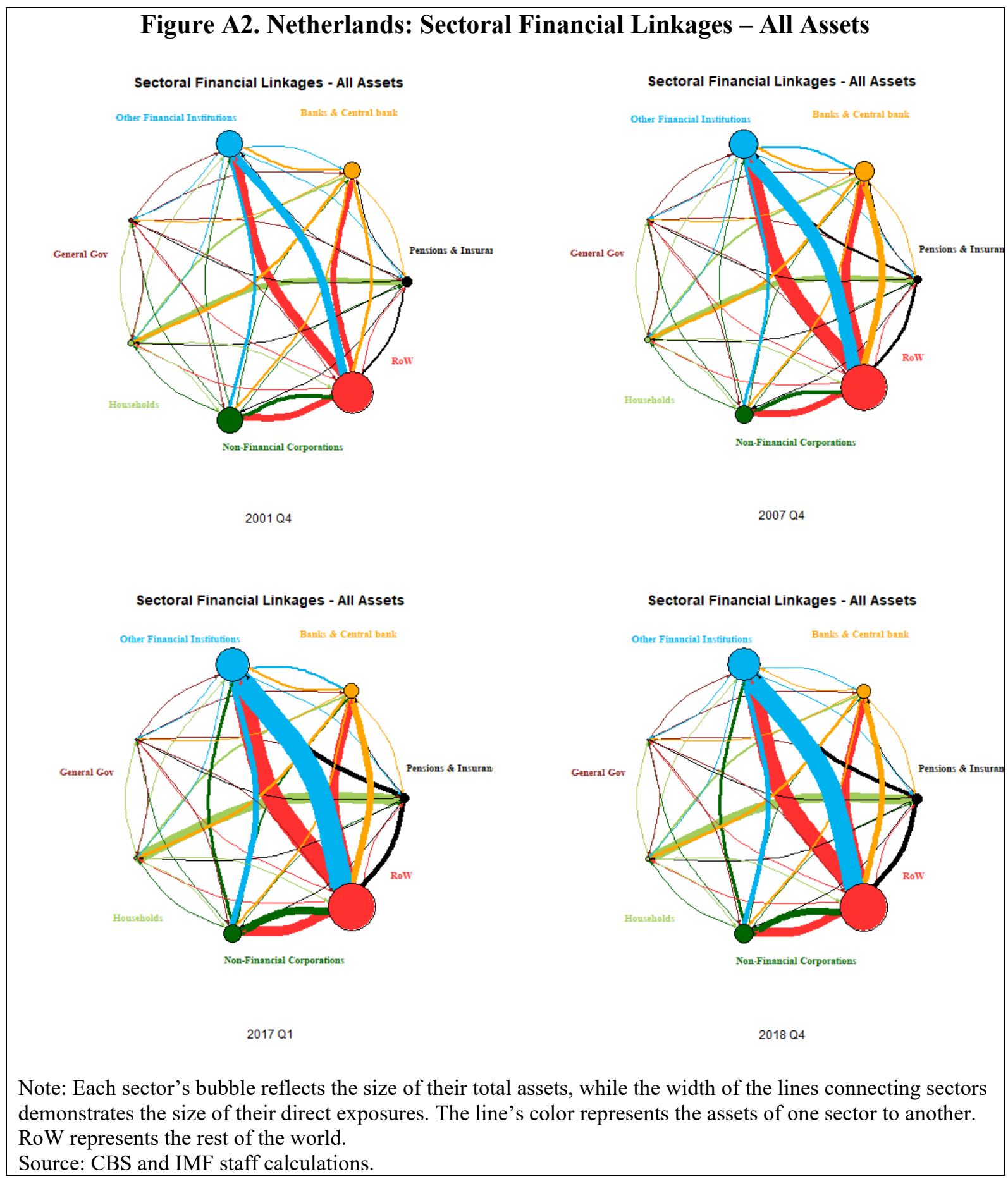




\section{AnNeX III. An OVERLAPPING Generations Model}

The household optimization problem is:

$$
\begin{aligned}
& \max _{C_{1}, C_{2}, C_{3}} U\left(C_{1}\right)+\beta \times U\left(C_{2}\right)+\beta^{2} \times U\left(C_{3}\right) \\
& \text { s.t. }\left\{\begin{array}{l}
C_{1}+S_{1} \leq(1-\alpha) W \\
C_{2}+S_{2} \leq(1-\alpha) W+(1+r) S_{1} \\
C_{3} \leq \lambda W+(1+r) S_{2}
\end{array}\right.
\end{aligned}
$$

A household chooses the levels of consumption to maximize the expected lifetime utility in equation (1). Individuals work in the first two periods, earning wage $W$ and contributing $\alpha$ share of wage to pension, save $S$ with the rate of return $r$, and receive pension income with a replacement rate of $\lambda$. The pension funds are subject to a regulatory requirement:

$$
\left(1+r_{p}\right)^{2} \alpha W+2\left(1+r_{p}\right) \alpha W+2 \alpha W \geq C R\left(\lambda W+\frac{\lambda W}{1+d}+\frac{\lambda W}{2(1+d)^{2}}\right)
$$

where $d$ is the regulatory (real) discount rate, and $r_{p}$ is the return on pension investment, both are positively correlated with $r$, and $C R$ is the minimum coverage ratio. We assume a uniform pension accrual.

We assume a constant relative risk aversion (CRRA) utility function,

$$
U(c)=\frac{c^{1-\theta}}{1-\theta} .
$$

The first-order conditions for a household are:

$$
\begin{aligned}
& U^{\prime}\left(C_{1}\right)=(1+r) \times \beta \times U^{\prime}\left(C_{2}\right) \\
& U^{\prime}\left(C_{2}\right)=(1+r) \times \beta \times U^{\prime}\left(C_{3}\right) .
\end{aligned}
$$

And we can derive the levels of consumption as shares of wage:

$$
\begin{aligned}
& \frac{C_{1}}{W}=\frac{\lambda+(1-\alpha)(2+r)(1+r)}{(1+r)^{2}+(1+r)[(1+r) \beta]^{\frac{1}{\theta}}+[(1+r) \beta]^{\frac{2}{\theta}}} \\
& \frac{C_{2}}{W}=\frac{\lambda+(1-\alpha)(2+r)(1+r)}{(1+r)^{2}+(1+r)[(1+r) \beta]^{\frac{1}{\theta}}+[(1+r) \beta]^{\frac{2}{\theta}}} \times[(1+r) \beta]^{\frac{1}{\theta}} \\
& \frac{C_{3}}{W}=\frac{\lambda+(1-\alpha)(2+r)(1+r)}{(1+r)^{2}+(1+r)[(1+r) \beta]^{\frac{1}{\theta}}+[(1+r) \beta]^{\frac{2}{\theta}}} \times[(1+r) \beta]^{\frac{2}{\theta}}
\end{aligned}
$$

Following the literature (Ciurila et al. 2020), we assume that $\theta=2$ and $\beta=0.98$. The minimum coverage ratio is 1.05 . The return on pension investment is higher than the return on personal savings due to better-managed pension investment, $r_{p}=r+2$. 
The pension discount rate follows the schedule in equation (7). We assume that the nominal discount rate would stay between 2 and 4 percent, and the long-term inflation rate is about 2 percent.

$$
d=\left\{\begin{array}{l}
0 \quad \text { if } r \leq 0 \\
r / 2 \quad \text { if } 0<r \leq 4 . \\
2 \text { if } r>4
\end{array}\right.
$$

The text chart shows that when interest rate declines, young households will increase their consumption since the substation effect dominates. In contrast, middle-aged households would reduce their consumption since the income effect dominates as they are closer to retirement. If the coverage ratios of pension funds are above the minimum requirement, both contribution rate and replacement rate could be maintained. However, if the coverage rates reach the minimum level, pension funds need to raise the contribution rate to maintain the replacement rate. In this case, both young and middle-aged households would reduce their consumption due to lower disposable income.

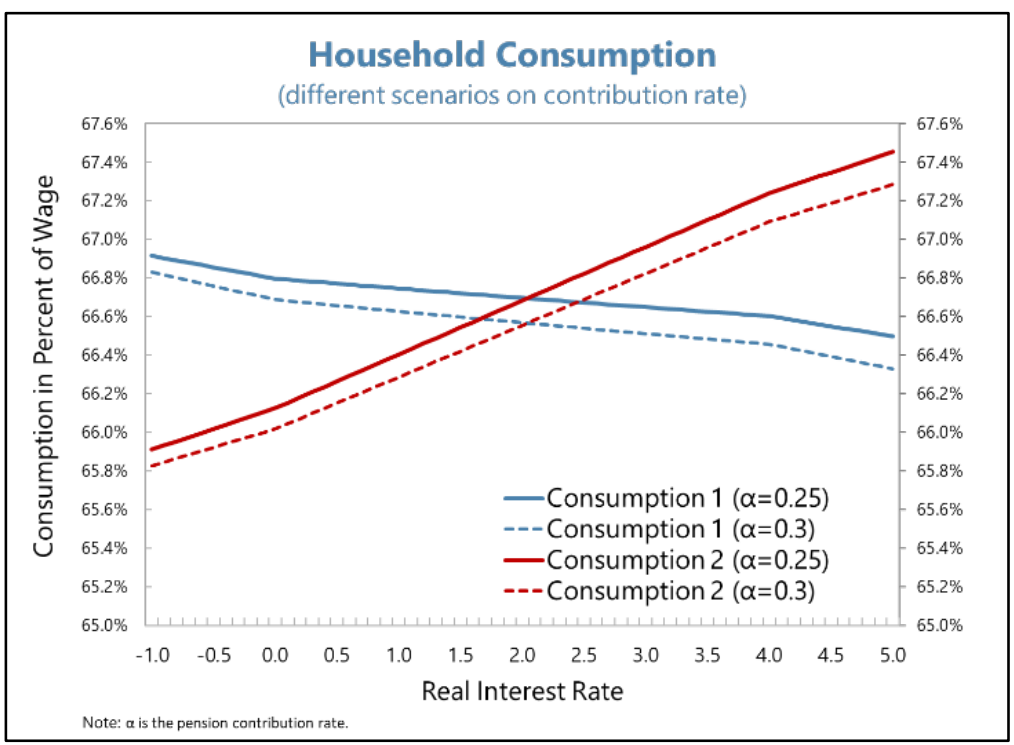




\section{Annex IV. Evolution of Dutch Pension Funds}

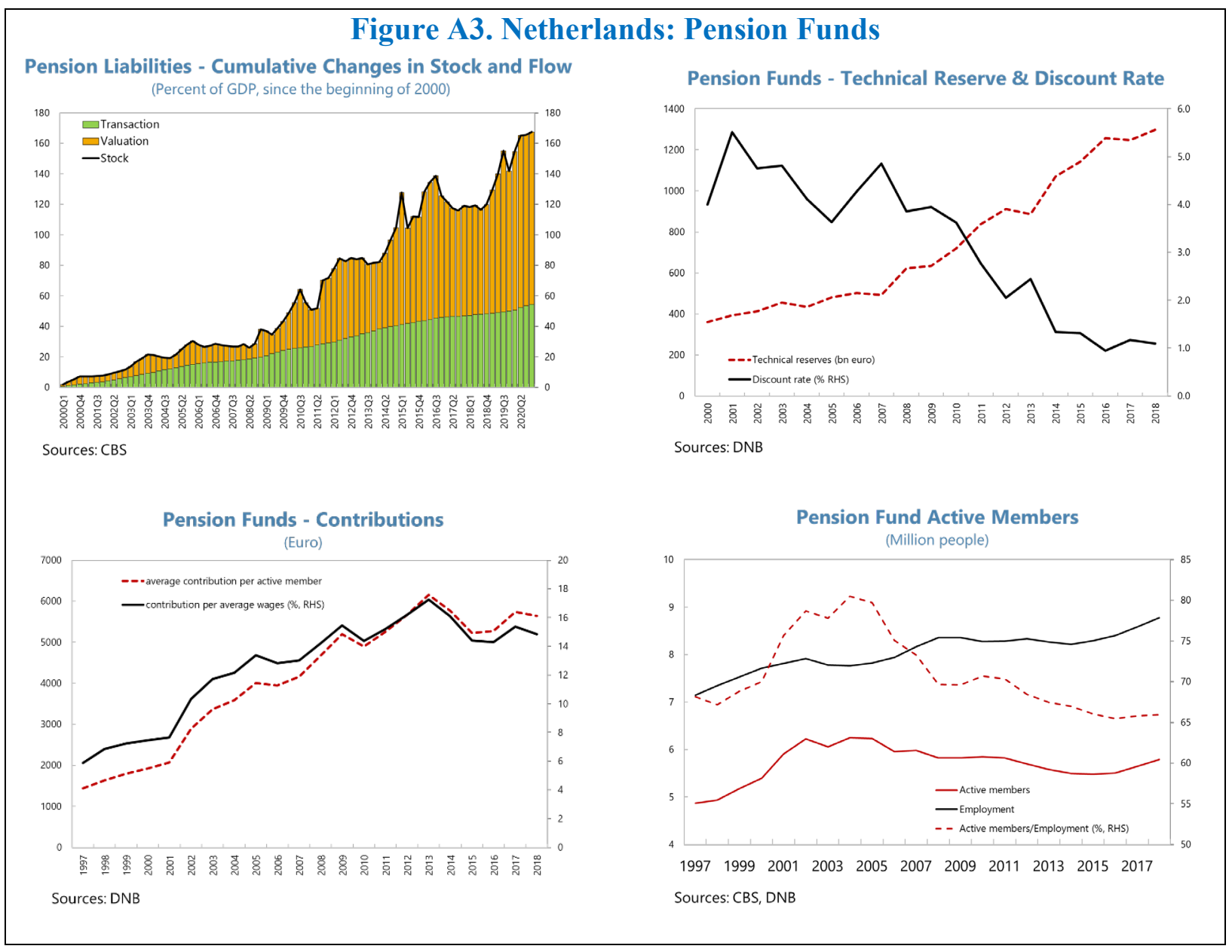




\section{REFERENCES}

Marco Arena, Ruo Chen, Alfredo Cuevas, and others, 2021, "Who Bore the Brunt of the Pandemic in Europe? Shifting Private Sector Stress to the Public Sector," International Monetary Fund, Departmental Papers Vol. 2021 Issue 015.

Roel Beetsma, Mirja Constandse, Frank Cordewener, Ward Romp, and Siert Vos, 2015, "The Dutch Pension System and the Financial Crisis," CESifo DICE Report, ISSN 1613-6373, ifo Institut - Leibniz-Institut für Wirtschaftsforschung an der Universität München, München, Vol. 13, Iss. 2, pp. 14-19.

Francesco G. Caloia, Stefan Hochguertel, and Mauro Mastrogiacomom, 2021, "Occupational pensions, macroprudential limits and the financial position of the self-employed," forthcoming.

Nicoleta Ciurila, Harro van Heuvelen, and Rob Luginbuhl, Bert Smid, 2020, "Are the savings of Dutch households optimal?”, CPB 2020.

Jurriaan Eggelte, Rini Hillebrand, Thomas Kooiman, and Guido Schotten, 2014, "Getting to the Bottom of the Dutch Saving Surplus," DNB Occasional Studies Vol 12-6.

André Geis and Oana Luca, 2021, "Real Estate in the Netherlands: A Taxonomy of Risks and Policy Challenges," IMF Working Paper WP/21/206.

Willem Heeringa, Paul Hilbers, Rob Nijskens, 2019, "Hot Property, The Housing Market in Major Cities," Springer Nature, 2019

Johannes Hers, Joost Witteman, and Ward Rougoor, 2018. "Balance Sheets, Income and Expenditure of Special Financial Institutions (SFIs): Facts, Figures and Possibilities for Impact Assessment", SEO Amsterdam Economics, 2018.

Alexander Klemm, Shafik Hebous, and Christophe Waerzeggers, 2021, "Capital Income Taxation in the Netherlands," IMF Working Paper WP/21/145.

International Monetary Fund (IMF), 2015, "Balance sheet analysis in Fund surveillance", IMF Policy Papers, 2015.

IMF, 2018, "Fundamental Drivers of House Prices in the Netherlands? A Cross-Country Analysis," Selected Issues Paper, International Monetary Fund, 2018.

IMF, 2019a, "Corporate Savings in the Netherlands," Selected Issues Paper, International Monetary Fund, 2019.

IMF, 2019b, "Self-Employment and Support for the Dutch Pension Reform," Selected Issues Paper, International Monetary Fund, 2019. 
Philip R. Lane and Gian Maria Milesi-Ferretti, 2017, "International Financial Integration in the Aftermath of the Global Financial Crisis", IMF working paper WP/17/115.

Mercer, 2020, “Mercer CFA Institute Global Pension Index 2020,” Mercer, 2020

Jante Parlevliet and Thomas Kooiman, 2015, "Wealth Formation of Dutch Households: a Policy Assessment.” DNB Occasional Studies Vol13-1. 